\title{
The effect of lengthening Life Expectancy on future pension and Long-Term Care expenditure in England, 2007 to 2032
}

Juliette Malley, Personal Social Services Research Unit

Juliette Malley ${ }^{1,2}$, Ruth Hancock ${ }^{3}$, Mike Murphy ${ }^{4}$, John Adams ${ }^{5}$, Raphael Wittenberg ${ }^{1}$, Adelina Comas-Herrera ${ }^{1}$, Chris Curry ${ }^{5}$, Derek King ${ }^{1}$, Sean James ${ }^{5}$, Marcello Morciano ${ }^{3}$, and Linda Pickard ${ }^{1}$ 1 Personal Social Services Research Unit, London School of Economics and Political Science 2 Personal Social Services Research Unit, University of Kent at Canterbury

3 University of East Anglia

4 Social Policy Department, London School of Economics and Political Science

5 Pensions Policy Institute 


\begin{abstract}
Background

The aim of this analysis is to examine the effect of different assumptions about future trends in life expectancy (LE) on the sustainability of the pensions and long-term care (LTC) systems. The context is the continuing debate in England about the reform of state pensions and the reform of the system for financing care and support.

\section{Methods}

Macro and micro simulation models are used to make projections of future public expenditure on LTC services for older people and on state pensions and related benefits, making alternative assumptions on increases in future LE. The projections cover the period 2007 to 2032 and relate to England.
\end{abstract}

\title{
Results
}

Results are presented for a base case and for specified variants to the base case. The base case assumes that the number of older people by age and gender rises in line with the Office for National Statistics' principal 2006-based population projection for England. It also assumes no change in disability rates, no changes in patterns of care, no changes in policy and rises in unit care costs and real average earnings by 2 per cent per year. Under these assumptions public expenditure on pensions and related benefits is projected to rise from 4.7 per cent of Gross Domestic Product (GDP) in 2007 to 6.2 per cent of GDP in 2032 and public expenditure on LTC from 0.9 per cent of GDP in 2007 to 1.6 per cent of GDP in 2032. Under a very high LE variant to the GAD principal projection, however, public expenditure on pensions and related benefits is projected to reach 6.8 per cent of GDP in 2032 and public expenditure on LTC 1.7 per cent of GDP in 2032.

\section{Conclusions}

Policymakers developing reform proposals need to recognise that, since future LE is inevitably uncertain and since variant assumptions about future LE significantly affect expenditure projections, there is a degree of uncertainty about the likely impact of demographic pressures on future public expenditure on pensions and LTC. 


\section{Contents}

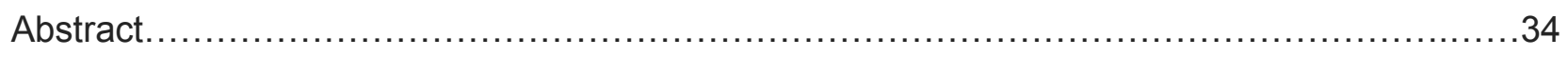

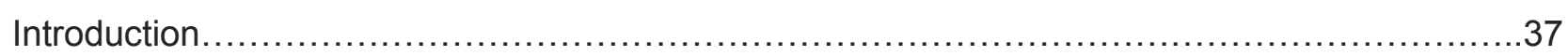

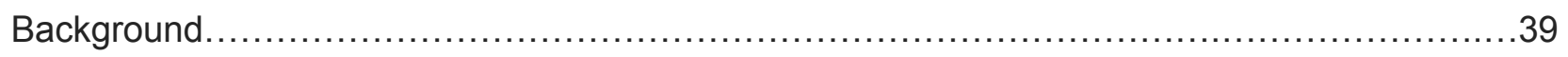

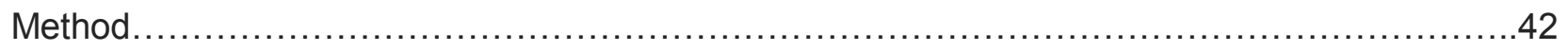



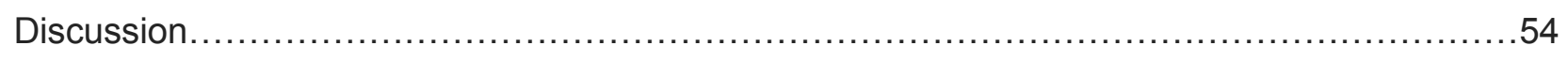



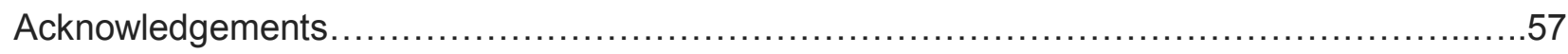

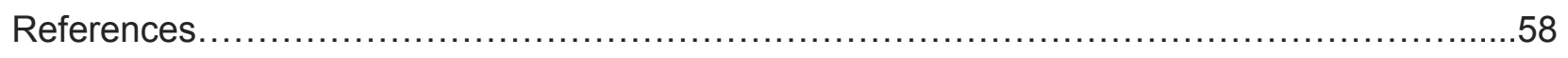

\section{List of Figures}

Figure 1 Total LTC expenditure by source under principal LE projection, England 2007 to 2032. 


\section{List of Tables}

Table 1 Past performance: Projected number of people aged 85 and over, Principal Projection, England and Wales.

Table 2 Comparison of Projected Life Expectancy, UK \& USA 2008 Official Principal Projections.....

Table 3 Projected numbers of older people, England 2007 to 2032, under four variant life expectancy assumptions.

Table 4a Pension expenditure, by expenditure source under variant life expectancy assumptions from 2007 to 2032, England (per cent of GDP). Annuity providers do not change their rates to reflect changes in life expectancy.....

Table 4b Pension expenditure, by expenditure source under variant life expectancy assumptions from 2007 to 2032, England (per cent of GDP). Annuity providers change their rates to reflect changes in life expectancy.

Table 5 Long-term care expenditure, by expenditure source under variant life expectancy assumptions from 2007 to 2032, England.

Table 6 Long-term care public expenditure as a percentage of GDP, under different life expectancy assumptions from 2007 to 2032, England. ...

Table 7 Public expenditure on long-term care and pensions as a percentage of GDP, under different life expectancy assumptions, England 2007 to 2032. 


\section{Introduction}

As their populations age, countries across the developed world are recognising the need to reconsider and reform their policies for older people, driven in large part by concerns over their future affordability and sustainability in the face of rising demand and increasing dependency ratios (the ratio of the non-working age population to the working age population). In England (and the UK more generally), recent debate has focused on the reform of the pensions and long-term care (LTC) systems. Whilst several reforms for pensions have been announced and legislated for, few have so far been enacted for LTC. Changes to the system for funding LTC are now expected following the publication in July 2011 of the report of the Commission on Funding of Care and Support (CFCS 2011) although it is not known yet whether the Commission's recommendations will be implemented. Despite the interconnectedness of the pensions and LTC systems, the debates concerning reform and the analysis of the reforms have so far taken place independently.

To develop reforms and analyse their effects, as well as plan and budget for the future, the UK Government and policy analysts have relied significantly on projection models, which, based on a series of documented assumptions, attempt to demonstrate the short and long-term effects and costs of different policies (Pensions Commission 2006; Wanless 2006; Her Majesty's Government 2010; CFCS 2011; Office for Budgetary Responsibility 2011; European Commission and Economic Policy Committee 2009). Underlying these models are projections of numbers of older people in years to come since this is a key driver of demand and expenditure on both pensions and LTC. The former because pensions are guaranteed to be paid to people for as long as they live, so that, subject to the impact of increases in the state pension age (SPA), increasing life expectancy (LE) means pensions are paid for longer terms. The latter because increasing LE also increases the number of years in poor health (unless all the years of LE gained are healthy years, which is unlikely to be the case (Jagger et al., 2007; Donald et al., 2010)), and the prevalence of disabling conditions many of which, such as dementia, are strongly related to old age (Organisation for Economic Cooperation and Development 2005; Jagger et al., 2009). The accuracy of the models is therefore highly dependent on the accuracy of the projections of numbers of older people.

For forecasting numbers of older people, the key factor is the levels of mortality experienced in years to come by those who are already in - or will enter - that age group, since the only other relevant factor, migration, is low at these ages. The main source of such forecasts for England is the Government's official population projections ${ }^{1}$. The level of mortality in a particular year across all ages is usually summarised by the indicator of period life expectancy (LE), the average number of additional years that a group of people would live if they experienced these levels of mortality for the rest of their lives. We also follow the convention that period LE is used, for example in ONS projections publications (e.g. ONS, 2010, Chapter 9), to summarise the level of mortality. However, in our modelling, we use the relevant detailed projected level of mortality at each age for each year. Period LE has increased steadily for more than 150 years and in a largely linear fashion

${ }^{1}$ See for example the national population projections, series pp2 produced by the Office for National Statistics (ONS). Analyses in this paper were undertaken using the 2006-based official population projections. The 2008-based projections had similar assumptions (ONS, 2010. p. 24). The 2010-based projections were published in October 2011 (available at http://www.ons.gov.uk/ons/rel/npp/national-populationprojections/2010-based-projections/index.html). These later sets could not be included in the analyses, but the projected figures are very similar to the earlier sets; for example, the projected numbers aged 85 and over in England and Wales in 2031 differ by less than 1 per cent between the 2006 and 2010-based projections (Table 1), so the main conclusions of the paper are not affected. 
over the last forty years. However, the projections made during this latter period have assumed that there would be a reduction in the observed rates of improvement in the years ahead of the base, sometimes assuming no further improvement in the longer term. The consequence is that LE has been consistently under-projected, leading to substantially lower numbers of older people, especially among the 'oldest old', those aged 85 and over (Murphy 1995; Keilman 2007; Shaw 2007). Under-projection of this kind can have serious consequences for analysing the effects, sustainability and future affordability of both pensions and LTC systems.

It is therefore important to recognise the limitations of the population projections and at the same time produce policy that is robust to such uncertainty. For this reason, it is common to produce a range of alternative projections for future years rather than a single set and this is the approach taken by the Government Actuary's Department (GAD) and more recently the Office of National Statistics (ONS) in the official population projections. ${ }^{2}$ To aid users the most plausible projection set is indicated and conventionally denoted as the principal variant (Office for National Statistics 2009: 8). The variants are frequently presented as plausible alternatives to the principal projection. The sensitivity of policy to changes in the assumptions on future trends in LE provides useful information to policymakers to ensure that their plans are robust to this uncertainty, although these variants do not have explicit probabilities of likelihood of occurrence attached to them (Abel et al., 2010).

The choice of the principal and variant projections is therefore important. The poor past performance of the principal projection, in the sense that it has consistently under-projected improvements in LE, also undermined the usefulness of the variant projections, since they have not adequately captured the 'funnel of doubt' associated with the principal projection. The Pensions Commission (2005) argued that at the time, the low LE variant was considered implausible by most experts, whereas this was not the case for the high LE variant. In recent years, ONS have upwardly revised mortality improvement such that the official projections now assume that overall mortality improvement in the future will be comparable to that actually experienced over corresponding periods in the past (Office for National Statistics 2009: 8). This means that, for example, the projected numbers of men aged 85 and over in 2031 in England and Wales is over twice as many in the 2008-based principal projection than projections made 14 years earlier, with over half a million more older men and women expected (Table 1). However, questions remain about the likely evolution of future trends in LE and in this context the plausibility of the current set of official projections and therefore the ability of the variants to support robust policy decisions.

\footnotetext{
${ }^{2}$ Population projections were previously undertaken by the GAD but transferred to ONS in 2006 .
} 


\section{Table 1 Past performance: Projected number of people aged 85 and over, Principal Projection, England and Wales}

\begin{tabular}{|lrrrrrrrr|}
\multicolumn{10}{c|}{ Thousands } \\
\hline & \multicolumn{10}{c|}{ Base year for projections } & & \\
\hline Males & $\mathbf{1 9 9 4}$ & $\mathbf{1 9 9 8}$ & $\mathbf{2 0 0 0}$ & $\mathbf{2 0 0 2}$ & $\mathbf{2 0 0 4}$ & $\mathbf{2 0 0 6}$ & $\mathbf{2 0 0 8}$ & $\mathbf{2 0 1 0}$ \\
Base year value & 228 & 269 & 286 & 285 & 293 & 344 & 383 & 418 \\
$\begin{array}{l}\text { Projection for 2031 } \\
\text { Females }\end{array}$ & 552 & 691 & 722 & 885 & 933 & 1086 & 1113 & 1071 \\
Base year value & 689 & 748 & 768 & 728 & 709 & 778 & 823 & 856 \\
Projection for 2031 & 1040 & 1130 & 1116 & 1352 & 1342 & 1483 & 1549 & 1518 \\
\hline
\end{tabular}

Source: M Murphy from ONS Series PP2 and Populations Projections Reports (various)

Using projection models of LTC and pensions, the aim of this paper is to examine the effect of different assumptions about future trends in LE on the sustainability and affordability of both the pensions and LTC systems, and, given the potential for reform of the LTC system, the effect under a selected LTC reform proposal. The focus is on providing estimates of the total likely future cost to the public purse, although we also present estimates of the likely income from private pensions and private expenditure on LTC. We do not consider here how costs would be financed. By considering the effect of future trends in LE on the pensions and LTC systems together, we also take a first step in drawing these debates together. Before presenting evidence from the projection models, we first consider how LE trends may develop in future years and provide some background to the pensions system, which is the same throughout the UK, the LTC system as it operates in England and the models used for projecting future expenditure.

\section{Background}

\section{Future trends in life expectancy}

There are sharply divergent views about how trends in LE may develop during this century: for example Christensen et al. (2009: 1139) pointed out "If the pace of increase in life expectancy in developed countries over the past two centuries continues through the 21st century, most babies born since 2000 in [countries] with long life expectancies will celebrate their 100 th birthdays. ... research suggests that ageing processes are modifiable and that people are living longer without severe disability". On the other hand, Olshansky et al. (2005: 1142) stated: "as a result of the substantial rise in the prevalence of obesity and its life-shortening complications such as diabetes, LE at birth and at older ages could level off or even decline within the first half of this century".

At present, overall age standardised mortality rates (both sexes combined) are improving at about 2.5 per cent per annum in England and Wales, but current trends are heavily influenced by patterns at ages where deaths are concentrated. In 2005, just over 50 per cent of deaths in England and Wales occurred to people born in the period around 1925 to1945. These birth cohorts, sometimes referred to as the 'Golden generations' have exhibited faster-than-average rates of mortality improvement in recent decades (Dunnell 2008: 19). Current British official mortality projections are based on the assumption that this group will enjoy advantages in future up 
to the highest ages (Office of Population Censuses and Surveys 1995; Office for National Statistics 2009). Thus the high levels of mortality improvement observed in recent years are assumed to be a transient phenomenon largely associated with those born around the period 1925-45 and that as these cohorts are replaced in the main mortality age groups by less favoured cohorts, rates of mortality improvement will fall in future. Current official projections assume that mortality improvement will decline to a value of about 1 per cent per annum in about 25 years time after the 'Golden generations' effect has worked itself out of the system. However, although the phenomenon of the 'Golden generations' was identified two decades ago, no clear-cut causal mechanisms have been established, and therefore the extent to which the current high annual rate of improvement is directly related to these cohorts or alternatively, whether it is a more generalised period phenomenon is contested. Future prospects are likely to depend on a number of factors, especially the obesity epidemic identified by Olshansky et al. above. However, the Government Office for Science (2007) recently concluded that any increase in obesity will have surprisingly little impact (less than a year) on the LE of the population, in a period when official projections assume that LE will rise in the next 50 years by around eight years for men and seven years for women. While obesity has a substantial impact on morbidity status, it is unlikely to have much impact on numbers of older people in the next quarter century or so, and in any case there will be offsetting factors such as lower levels of smoking among later cohorts (see for example Murphy and Di Cesare 2012 (forthcoming)).

Official projections in all countries take different views on future trends. Although British official projected increases in LE assume that current rates of improvement will decrease substantially in future decades, nevertheless they are among the most optimistic in the developed world, so that by 2030 LE in the United Kingdom is expected to be about four years greater than in the US, at which point US values for both sexes combined would only be about the same as current UK values (Table 2).

\section{Table 2 Comparison of Projected Life Expectancy, UK \& USA 2008 Official Principal Projections}

\begin{tabular}{|lccc|}
\multicolumn{4}{c}{ Additional years of LE from 2010 } \\
\hline Males & $\mathbf{2 0 1 0}$ & $\mathbf{2 0 2 0}$ & $\mathbf{2 0 3 0}$ \\
US & & & \\
UK & 75.7 & 1.3 & 2.7 \\
Females & 78.5 & 2.7 & 4.3 \\
US & & & \\
UK & 80.8 & 1.2 & 2.3 \\
\hline
\end{tabular}

Source: http://www.census.gov/population/www/projections/2008projections.html and http://www.ons.gov.uk/ons/rel/lifetables/period-and-cohort-life-expectancy-tables/2008-based/index.html

\section{Pension policy in the UK}

In the UK, the state retirement pension is payable to people who have reached SPA and have made, or been credited with, sufficient National Insurance Contributions. There are two main 
components of the current state pension. The first is the basic state pension (BSP) which is unrelated to earnings. The second is an additional earnings-related pension. The formula through which this additional pension is related to earnings has changed over time. Non state pensions are an important component of the UK pension system. They include employer-based schemes and pensions arranged by individuals. It is possible to 'contract out' of the earnings-related component of the state pension by making contributions to an appropriate employer or individual pension. Means-tested state benefits exist to supplement the incomes of low income pensioners. Pension Credit (PC) is a general income supplement. Housing Benefit provides help towards paying rent. Council Tax Benefit reduces liability for the local property-based Council Tax. ${ }^{3}$ Changes in LE affect spending on state pensions mainly through their effects on the numbers of people over SPA rather than for example, through the age composition of the older population as there are only minor age-related supplements to pensions.

Following the report of the Pensions Commission (2005) and the 2007 Pensions Act, a number of reforms to UK pensions are in train. They address concerns over the long-term affordability of state pensions in the face of rising longevity and the inadequacy of pensions and substantial reliance on means-tested supplements among some groups. Pension inadequacy has been fuelled in part by the falls in the proportion of employees contributing to non-state pensions, the trend away from defined benefit (DB, 'final salary') pension schemes towards defined contribution (DC) schemes and insufficient private pension contributions by those on low to middle earnings. The key changes now coming into force include: a rise in the SPA to 66 by 2026, 67 by 2036 and 68 by 2046; changes to the qualifying conditions for the BSP so that more people will qualify for the full amount and a commitment to link annual increases in the BSP to earnings rather than prices; measures to limit the spread of means-tested benefits especially PC; and the introduction of a new low costs national pension savings scheme (NEST) which requires employers to enrol eligible employees automatically into a work-based pension scheme, with minimum employee and employer contributions, unless the employee explicitly opts out. The pension projections in this paper use these policies as the basis for projection.

The Coalition Government has recently introduced legislation in the Pensions Act 2011 to bring forward the increase in SPA so that SPA becomes 65 for women by 2018 and 66 for men and women by 2020 . It has also changed the basis of indexation of pensions in payment for state pensions; SERPS and state second pension (S2P) benefits in payment will in future be increased in line with the Consumer Prices Index (CPI) rather than the Retail Prices Index (RPI), and the Government also intends to in future provide a 'triple guarantee' to increase the BSP each year by the highest of consumer price inflation, earnings rises or 2.5 per cent (HM Treasury 2010), as opposed to the previous policy of earnings indexation from 2012. The Government has also started a consultation process considering more radical reform of the state pension system (Department for Work and Pensions 2011).

\section{Long-term care policy in England}

LTC is generally considered to mean help with nursing tasks, personal care tasks such as dressing and bathing, help with domestic tasks such as shopping and preparing meals, and nursing care

\footnotetext{
${ }^{3}$ There are also non means-tested benefits for pensioners with significant disabilities. In this paper we treat the component of these that are used to fund LTC as LTC expenditure.
} 
(Comas-Herrera et al., 2004). Public support for all LTC (except the nursing element of care) in England is both needs and means-tested. For residential services in nursing and residential care homes, the means test takes into account the income and assets (in most cases including any housing wealth) of residents. Those with assets over an upper limit, £23,250 in 2011/12, are not eligible for public support with the costs of care. Those with assets below this level are required to pay some of the costs of their care, the amount depending mainly on their income. Local authorities (LAs) have discretion over how they charge for community-based care services such as home care, although there are national guidelines which set out common principles to which LAs must adhere in determining how much to charge users (Department of Health 2003). The needs tests are also carried out by LAs, although there are national guidelines, which set out principles that LAs should take into consideration (Department of Health 2010).

Sustained debate over the past decade or so has produced a number of proposals for reform, which all present more universal systems. Thus a Royal Commission on LTC suggested a policy of 'free' personal care (Royal Commission on Long-term Care 1999); the Wanless Social Care Review (Wanless 2006) suggested a 'partnership' scheme, which was recommended by the Labour Government's Green Paper (Her Majesty's Government 2009) and marked for consideration in the terms of reference of the Coalition's Commission on the Funding of Care and Support (Secretary of State for Health 2010); and the International Longevity Centre suggested a national insurance approach (Lloyd 2008). In the lead up to the 2010 election, the debate around LTC intensified and the then Labour government proposed a National Care Service, mirroring the National Health Service, and creating a fully universal care system for LTC (HM Government 2010).

A stumbling block, however, in proposals for all of these reform options is how they should be funded, with concerns over the future affordability and sustainability of the options. The Royal Commission proposed funding free personal care through general taxation but, although this was adopted in Scotland, it was rejected in England on grounds of affordability (Department of Health 2000). Unable to decide on how best to raise funds for the National Care Service, the Labour government proposed setting up a Commission (Her Majesty's Government 2010). The Coalition Government established the Commission on Funding Care and Support (CFCS), whose terms of reference stated the need to make recommendations for an affordable and sustainable funding system (Secretary of State for Health 2010). The Commission reported in July 2011. Its main recommendation was that individuals' lifetime contributions towards their social care costs - which are currently potentially unlimited - should be capped. After the cap is reached, individuals would be eligible for full state support. The commission recommended that this cap should be between $£ 25,000$ and $£ 50,000$, with $£ 35,000$ considered to be the most appropriate and fair figure.

\section{Method}

To explore the effect of LE on expenditure of LTC and pensions in England over the period 2007 to 2032 we use simulation modelling techniques. More specifically we have a suite of several models which are linked in two different ways: the models share parameters, so they are based on the same assumptions, and the output from one model is used as input to another model. 
To project expenditure on LTC, we use two models: the CARESIM micro-simulation model and the Personal Social Services Research Unit (PSSRU) aggregate LTC finance model. The PSSRU model is cell-based: it divides the current and projected future population into a large number of sub-groups or 'cells'. It simulates future demand for LTC and disability benefits for each of these groups, based on analysis of a sample of older people from the 2001 General Household Survey (GHS) ${ }^{4}$. Adjustments are made to the GHS analysis to include the residential care population and to reflect changes in the targeting of publicly-funded care provision since 2001 (Wittenberg et al., 2006). CARESIM simulates the incomes and assets of future cohorts of older people and their ability to contribute towards care home fees or the costs of home-based care, should such care be needed (Hancock et al., 2003). It is based on a pooled sample of older people from the 2002/3, $2003 / 4$ and $2004 / 5$ rounds of the Family Resources Survey (FRS) with money values uprated to the base year (here 2007) ${ }^{5}$. Together these two models can be used to project future expenditure on LTC by source of expenditure, under different funding reform options.

The PSSRU model output on the characteristics of people requiring LTC is used as input to CARESIM to adjust the FRS sample to be representative of people receiving different LTC services in the projection year. CARESIM then simulates for each type of service the ability of older people to contribute to their care costs and the source of income used to pay for care. CARESIM output is used to break down expenditure in the PSSRU model into its constituent components and funding sources, i.e. NHS, Personal Social Services, social security disability benefits and private money (Hancock et al., 2007). The projected levels of expenditure by each of these sources are compared with projected economic output, Gross Domestic Product (GDP). ${ }^{6}$ Therefore, using the input from CARESIM, the PSSRU model can be used to make projections both of the future balance between public and private expenditure on LTC and of the sustainability of the system with respect to economic growth measured through GDP. In addition CARESIM can be used to explore the distributional implications of policies, although in this paper our focus is on aggregate results.

Expenditure on pensions is projected using the Pension Policy Institute's (PPI) aggregate model (Steventon 2005). Outputs from this model include projections of government expenditure on pensions and of the private pension system. The model is cell-based. At its heart is a projection of the labour market in terms of the number of employees and self-employed people in each future year, by age, gender and their earnings band. Future expenditure on the earnings-related components of the state pension is estimated based on the projection of the labour market. BSP is projected by 'ageing' the existing generation of pensioners and simulating entitlements of future generations making assumptions on how entitlements are likely to change over time given current and planned changes to policy. Flows into and out of non-state pension schemes, and the associated cost of tax relief on contributions to them, are projected distinguishing a number of

\footnotetext{
${ }^{4}$ The 2001 GHS data are used since these are still the most detailed source of data on social care service receipt. Subsequent GHS/General Lifestyle Surveys did not collect data on service receipt and levels of disability. These data were also not available from other sources.

${ }^{5}$ The PSSRU model output that is used to adjust CARESIM output to be representative of the population receiving care also adjusts the relevant demographic composition of the FRS sample used in CARESIM to the projection year.
}

${ }^{6}$ Short-term GDP and cash deflators based on 30th November 2008 estimates. Long term GDP projections are based on 2008 budget report (HM Treasury 2008). The choice of GDP projections reflects the timing of the model revisions. 
different types of pensions, for example funded and unfunded, DB and DC employer-based schemes and personal pensions and the new NEST.

To project the income and assets of future older people, CARESIM simulates the future evolution of income from pensions for current generations of pensioners. The PPI pension models and CARESIM are not linked in any formal way but the policy assumptions on the evolution of state pension and means-tested benefit income are the same in the two models, ensuring consistency with each other.

The PPI pension model is UK based whereas the LTC projections presented in this paper are for England. Total public expenditure across the two sectors as a proportion of GDP is estimated as the sum of the projected share of GDP spent on publicly-funded LTC in England and the projected share of GDP spent on state pensions in the UK. The result gives an indication of the combined cost to the state of pensions and LTC but is an approximation, to the extent that there may be differences between England and the UK in the underlying proportions.

\section{Model assumptions}

The simulation models use a number of assumptions about the evolution of future trends in the socio-demographic and economic drivers of (demand and) expenditure for LTC and pensions, and the evolution of LTC and pensions policy. A set of assumptions is chosen as the 'base case'. For the socio-demographic and economic drivers these represent our best guess based on our knowledge of the literature and experience. For the evolution of policy we implement only legislated-for changes and do not make any assumptions about how policy may change, for example, in response to demographic changes or changes in government. The base case assumptions are shown in Box 1. 


\section{Box 1 Key assumptions of the base case}

- The number of people by age and gender changes in line with the GAD 2006-based principal population projections for England (for LTC) or UK (for pensions).

- Marital status changes in line with GAD 2006-based marital status and cohabitation projections for England and Wales.

- Prevalence rates of disability by age and gender remain unchanged, as reported in the 2001/2 GHS for Great Britain for household population (and assuming that all those in care homes are disabled).

- Home-ownership rates, as reported in the pooled 2003/4, 2004/5 and 2005/6 FRS, change in line with projections produced by the CARESIM model.

- The proportions of older people receiving informal care, formal community care services, residential care services and disability benefits remain constant by age, disability and other needs-related characteristics.

- Health and social care unit costs rise by 2 per cent per year in real terms (but non-staff revenue costs remain constant in real terms). Average earnings increase by 2 per cent per year in real terms. Real GDP rises in line with 2008 HM Treasury assumptions.

- The supply of formal LTC will adjust to match demand and demand will be no more constrained by supply in the future than in the base year.

- The LTC funding system remains unchanged as the current system for England.

- State pensions and means-tested benefits for pensioners follow policy as it was before the recent Coalition Government changes currently going through Parliament i.e. the BSP is uprated in line with earnings from 2012, the Guarantee Credit level in PC, Housing and Council Tax Benefit is linked to assumed earnings growth, as is the savings credit threshold until 2014 after which it is linked to price inflation as measured by the Retail Price Index.

- A number of assumptions have been made concerning private pensions, including the introduction of eligible individuals auto-enrolment into workplace pension schemes from 2012. It is assumed that approximately one-third of eligible employees opt-out after being auto-enrolled, and that employers who already offer pension provision will change the basis of their schemes in line with survey evidence. It is also assumed that the shift in pension provision in the private sector from DB to DC continues, with 80 per cent of the members in DB schemes in the private sector switching to DC schemes by 2020. Further details of the full range of assumptions made concerning private pension provision can be found in other PPI publications (for example PPI 2007)

- Future entitlement to state benefits is assumed to rise, following the reduction of the required number of years for full benefit to 30 years and the conversion of 'Home Responsibilities Protection' into National Insurance credits. 


\section{Variant life expectancy assumptions}

In the case of official projections, the 2006-based principal variant assumes a 1 per cent underlying rate of improvement in mortality, so that at most ages annual mortality improvement rates will be 1 per cent per year by 2031 and will continue at that rate of improvement thereafter. However, for those born between 1923 and 1940, rates of annual improvement are assumed to remain consistently higher with a peak value of 2.5 per cent per year from 2031 for those born in 1931 .

The official projections include two LE variants - a low and high variant - with underlying 0 per cent and 2 per cent per year improvements in mortality, respectively, with the same additional improvement as in the principal projection for those born in the period 1923 to 1940 . These variant assumptions are "intended as plausible alternatives [to the principal assumptions] and not to represent upper or lower limits for future demographic behaviour" (Office for National Statistics 2010: 89). Given the high rates of mortality improvement seen in the 'Golden Generations', an underlying 3 per cent per annum rate of improvement in mortality does not seem implausible. For this reason we have also included a 'very high' LE variant, with an underlying rate of improvement in mortality of 3 per cent per annum. This model assumes that the accelerating rate of mortality improvement experienced in recent decades will continue but then stabilise at an annual rate just above the current rate of improvement of about 2.5 per cent per annum. The assumption that cohorts born around 1930 will maintain an advantage over surrounding cohorts is retained since there are both empirical and theoretical grounds to expect those born before or at the time of the First World War to be relatively disadvantaged at older ages (Murphy 2009). While these assumptions are optimistic, they do not appear to be less plausible than the assumption that mortality improvement will essentially cease in about two decades time, as in the present low LE variant.

Although it is well-known that lower socioeconomic groups have shorter life expectancies than those in higher socioeconomic groups (Office for National Statistics; Marmot et al., 2010), no allowance is made for the effect that that this may have on LTC and pension expenditure. Improvements in LE are assumed to affect all population groups equally rather than, for example, benefiting those on higher incomes more than the less well-off (Nazroo et al., 2008), as there are no projections of LE by socio-economic status.

\section{Variant long-term care policy assumptions}

In order to illustrate the effects of a LTC funding system in which the state meets some of the costs of care without a means test, we chose to model a version of the 'partnership' scheme. Under a partnership scheme, everyone who qualifies for care and support on the basis of their care needs would be entitled to have a set proportion of their basic care and support costs met by the state. Under a cap as recommended by the CFCS, everyone who qualifies for care would be entitled to free care after their contribution to their care costs had reached a prescribed cap. The costs of either of these reform proposals would depend on the details of the scheme, so that they could potentially have similar costs to public funds depending on the specifics of the schemes. 
The version of the partnership scheme modelled here is based on the previous Government's Green Paper specification, where the state meets a third of the care costs (Her Majesty's Government 2009). We assume that all those who qualify for care are eligible to have one-third of their personal care costs met by the state. We thus interpret 'care and support' costs as meaning only personal care, which is consistent with much of the recent debate and the policy of free personal care which operates in Scotland. Labour's Green Paper, like the Wanless Social Care Review, proposed a progressive element to the scheme, such that those with fewer means receive more support to meet the costs of their care. To model the progressive element, we assume those people who are entitled to a state contribution of more than one-third of the costs of their assessed care needs under the current funding system would be entitled to the same level of state support under the partnership scheme.

We do not explore here an increase in demand arising from this policy. Eligibility for care and support, however defined, is determined according to the pattern of receipt of privately-and publicly-funded home care under the current system (and the proportion of home care that is for personal care tasks under the partnership scheme). Greater availability of state funding could change behaviour leading to more people coming forward for formal services and larger care packages. Increased demand could come from people currently outside the system managing on their own or managing with the support of family and friends.

\section{Results}

Assuming LE grows in line with the principal ONS population projections, the numbers of people aged 65 or over will rise by 64 per cent over the period from 2007 to 2032 from roughly 8 million to 13.4 million. However, as Table 3 shows depending on the variant chosen the increase in numbers of people over the period could be anywhere between 59 and 75 per cent, a difference of 1.4 million older people. The 'oldest old' age group, people over 85 is anticipated to grow the fastest, by 136 per cent under the principal projection. Uncertainty in the projections is greatest at the oldest ages, when the need for care is greatest. Thus the actual increase over the period could be anywhere between 114 and 181 per cent, a difference of around 0.75 million people. 
Table 3 Projected numbers of older people, England 2007 to 2032, under four variant life expectancy assumptions

\begin{tabular}{|c|c|c|c|c|c|c|c|c|}
\hline & & 2007 & 2012 & 2017 & 2022 & 2027 & 2032 & $\begin{array}{r}\text { millions } \\
\text { percentage } \\
\text { change } \\
\mathbf{2 0 0 7 - 2 0 3 2}\end{array}$ \\
\hline \multirow{2}{*}{ LLE } & all 65 and over & 8.16 & 9.01 & 9.97 & 10.77 & 11.80 & 12.93 & 59 \\
\hline & all 85 and over & 1.10 & 1.23 & 1.40 & 1.63 & 1.89 & 2.34 & 114 \\
\hline \multirow{2}{*}{ PLE } & all 65 and over & 8.16 & 9.05 & 10.05 & 10.94 & 12.08 & 13.39 & 64 \\
\hline & all 85 and over & 1.10 & 1.25 & 1.44 & 1.70 & 2.03 & 2.58 & 136 \\
\hline \multirow{2}{*}{ HLE } & all 65 and over & 8.16 & 9.09 & 10.14 & 11.09 & 12.36 & 13.85 & 70 \\
\hline & all 85 and over & 1.10 & 1.26 & 1.48 & 1.78 & 2.17 & 2.83 & 158 \\
\hline \multirow{2}{*}{ VHLE } & all 65 and over & 8.16 & 9.13 & 10.23 & 11.26 & 12.65 & 14.31 & 75 \\
\hline & all 85 and over & 1.10 & 1.28 & 1.52 & 1.86 & 2.32 & 3.08 & 181 \\
\hline
\end{tabular}

1 LLE low life expectancy variant, PLE principal life expectancy projection, HLE high life expectancy variant, VHLE very high life expectancy variant

Source: ONS 2006-based population projections, \& VHLE projections prepared by M Murphy

\section{Future pension expenditure}

\section{Sensitivity to changes in life expectancy assumptions}

As table $4 \mathrm{a}$ and $\mathrm{b}$ show, improvements in mortality will increase state spending on pensions and related benefits using our stated assumptions on state pensions policy. Under the principal LE assumption, such spending is projected to increase from 4.7 per cent of GDP in 2007 to 6.2 per cent by 2032. Should mortality rates decline faster than under the principal LE assumption then state spending will increase more, potentially reaching 6.8 per cent of GDP under the very high LE assumption by 2032. 
Table 4a Pension expenditure, by expenditure source under variant life expectancy assumptions from 2007 to 2032, England (per cent of GDP). Annuity providers do not change their rates to reflect changes in life expectancy

\begin{tabular}{|rlrrrrrr|}
\hline & & \multicolumn{1}{c}{ Percentage } \\
& State & $\mathbf{2 0 0 7}$ & $\mathbf{2 0 1 2}$ & $\mathbf{2 0 1 7}$ & $\mathbf{2 0 2 2}^{*}$ & $\mathbf{2 0 2 7}$ & $\mathbf{2 0 3 2}$ \\
& Private & 4.7 & 4.8 & 5.1 & 5.3 & 5.5 & 6.2 \\
& Total & 5.8 & 6.1 & 6.3 & 6.2 & 6.0 & 5.9 \\
& & $\mathbf{1 0 . 6}$ & $\mathbf{1 1 . 0}$ & $\mathbf{1 1 . 3}$ & $\mathbf{1 1 . 5}$ & $\mathbf{1 1 . 5}$ & $\mathbf{1 2 . 1}$ \\
& State & & & & & & \\
& Private & 4.8 & 4.9 & 5.2 & 5.4 & 5.7 & 6.4 \\
& Total & 5.8 & 6.2 & 6.3 & 6.2 & 6.1 & 6.0 \\
& & $\mathbf{1 0 . 6}$ & $\mathbf{1 1 . 1}$ & $\mathbf{1 1 . 4}$ & $\mathbf{1 1 . 7}$ & $\mathbf{1 1 . 8}$ & $\mathbf{1 2 . 4}$ \\
& State & & & & & & \\
& PHLE & 5.0 & 5.1 & 5.4 & 5.7 & 6.0 & 6.8 \\
& Private & 5.8 & 6.2 & 6.3 & 6.3 & 6.2 & 6.2 \\
& Total & $\mathbf{1 0 . 8}$ & $\mathbf{1 1 . 3}$ & $\mathbf{1 1 . 7}$ & $\mathbf{1 2 . 0}$ & $\mathbf{1 2 . 2}$ & $\mathbf{1 3 . 0}$ \\
\hline
\end{tabular}

1 PLE principal life expectancy projection, HLE high life expectancy variant, VHLE very high life expectancy variant 2 State Provision includes Basic State Pension, Additional State Pension, Pension Credit, Housing Benefit and Council Tax Benefit

3 Private Provision includes workplace pensions, both private and public sector and individual pension provision ${ }^{*}$ Projections are based on the assumption that SPA is 65 in 2022. Changes to legislation since this modelling took place now mean SPA will be 66 .

Source: ONS PPI model estimates

Table 4b Pension expenditure, by expenditure source under variant life expectancy assumptions from 2007 to 2032, England (per cent of GDP). Annuity providers change their rates to reflect changes in life expectancy

\begin{tabular}{|c|c|c|c|c|c|c|c|}
\hline & & & & & & \multicolumn{2}{|c|}{ Percentage } \\
\hline & & 2007 & 2012 & 2017 & $2022^{*}$ & 2027 & 2032 \\
\hline & State & 4.7 & 4.8 & 5.1 & 5.3 & 5.5 & 6.2 \\
\hline & Private & 5.8 & 6.1 & 6.3 & 6.2 & 6.0 & 5.9 \\
\hline \multirow[t]{3}{*}{ PLE } & Total & 10.6 & 11.0 & 11.3 & 11.5 & 11.5 & 12.1 \\
\hline & State & 4.8 & 4.9 & 5.2 & 5.4 & 5.7 & 6.4 \\
\hline & Private & 5.8 & 6.1 & 6.2 & 6.2 & 6.1 & 5.9 \\
\hline \multirow[t]{3}{*}{ HLE } & Total & 10.6 & 11.0 & 11.4 & 11.6 & 11.8 & 12.4 \\
\hline & State & 5.0 & 5.1 & 5.4 & 5.7 & 6.0 & 6.8 \\
\hline & Private & 5.8 & 6.1 & 6.3 & 6.2 & 6.1 & 6.0 \\
\hline VHLE & Total & 10.8 & 11.3 & 11.7 & 11.9 & 12.1 & 12.8 \\
\hline
\end{tabular}

1 PLE principal life expectancy projection, HLE high life expectancy variant, VHLE very high life expectancy variant 2 State Provision includes Basic State Pension, Additional State Pension, Pension Credit, Housing Benefit and Council Tax Benefit

3 Private Provision includes workplace pensions, both private and public sector and individual pension provision.

* Projections are based on the assumption that SPA is 65 in 2022. Changes to legislation since this modelling took place now mean SPA will be 66 .

Source: ONS PPI model estimates 
The effect of improvements in mortality on aggregate income from private pensions is more nuanced. The income that pensioners receive from private pensions is dependent on a number of factors. If the pensioner holds a DB pension, the factors that will affect the income that is received are their final salary, the accrual rate and the length of time that the pension will be in payment. However, if the pensioner holds a DC pension, the factors that need to be considered are the contribution rate, the annuity rates used by the annuity provider and the length of time that the pension will be in payment. As table 4a shows, assuming no change to annuity or accrual rates, total private pension income is projected to increase under the principal LE assumption from 5.8 per cent of GDP in 2007 to 5.9 per cent in 2032. Should LE improve faster, private income from pensions could rise to 6.0 per cent of GDP under the high LE assumption and 6.2 per cent under the very high LE assumption.

However, providers of private pensions may react to mortality improvements by reducing the annuity rates that are offered. In that case, as table $4 \mathrm{~b}$ shows, income from private pensions would not rise as much, reaching only 5.9 per cent of GDP by 2032 under the high LE assumption and 6.0 per cent under the very high LE assumption.

\section{Future long-term care expenditure}

\section{Sensitivity to changes in life expectancy assumptions}

Under the principal LE assumptions, total real expenditure on LTC will rise from $£ 17.5 \mathrm{bn}$ in 2007 to $£ 49.9$ bn (2007 prices) in 2032, an increase of 185 per cent. Although both private and public expenditure increase over time, by 212 per cent and 169 per cent respectively, over time an increasing proportion of total expenditure is from private sources (see figure 1). In 2007, 36 per cent of total expenditure is from private sources (nine per cent user charges and 27 per cent is self funded), but by 2032, 40 per cent of expenditure will be from private sources (8 per cent user charges and 32 per cent is self funded). By contrast, in 2007, 64 per cent of total expenditure is from public sources (defined as NHS, Personal Social Services (PSS) and social security disability benefits) but by 2032, 60 per cent of expenditure will be from public sources, the greatest difference being in PSS expenditure which decreases by three percentage points from 39 per cent to 36 per cent. Over the same period NHS expenditure stays relatively steady at around 21.5 per cent and expenditure on disability benefits used to fund care decreases from four to 3 per cent. 


\section{Figure 1 Total LTC expenditure by source under principal LE projection, England 2007 to 2032}

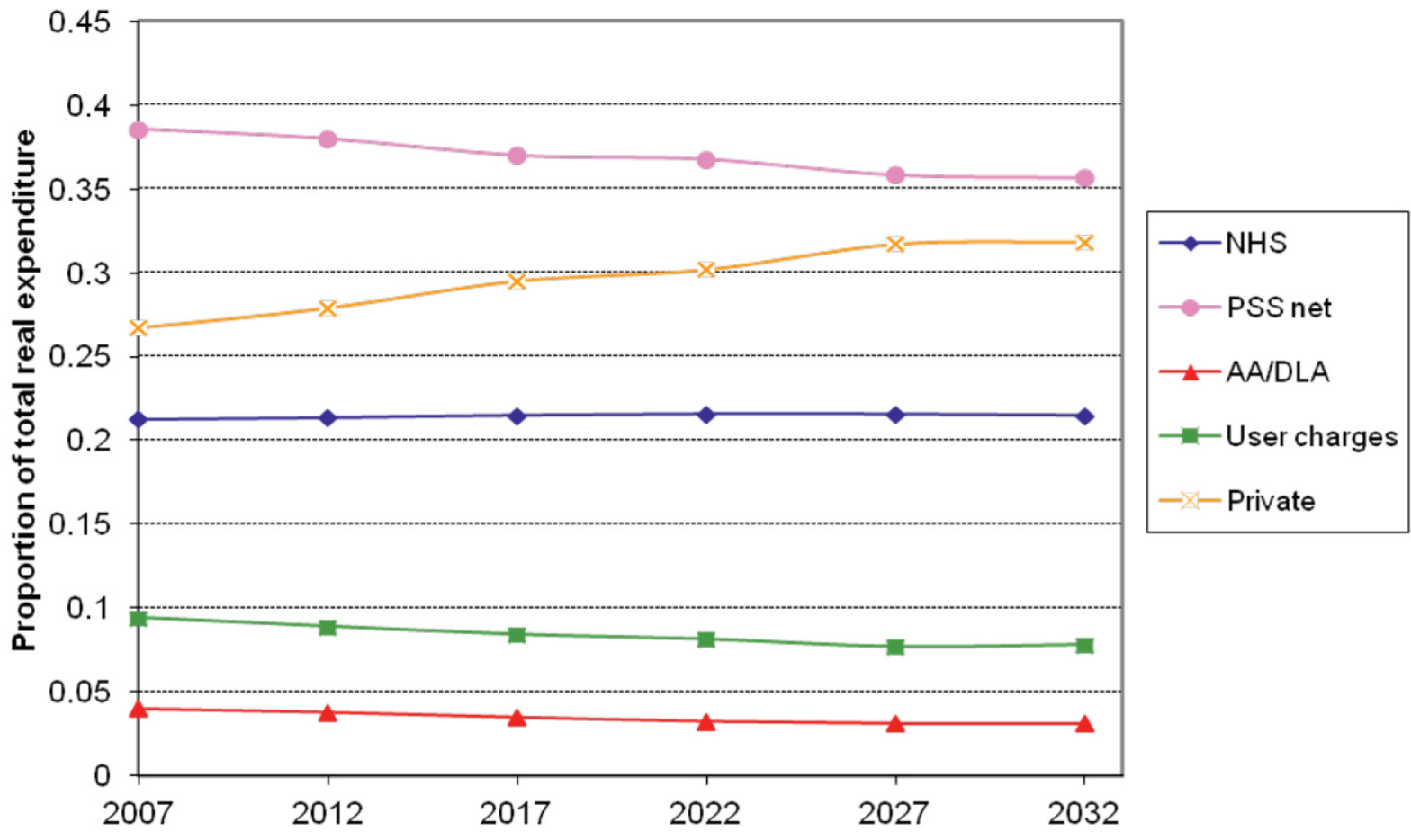

The alternative LE assumptions have a marked effect on both public and private real expenditure (see Table 5), although the proportion of total expenditure from each source, as shown in figure 1, remains constant across the LE variants because we do not allow for any relationship between LE and income or wealth. Under the high LE variant total expenditure on LTC is projected to rise from $£ 17.5$ bn in 2007 to $£ 52.8$ bn by 2032, an increase of 201 per cent. By contrast, under low LE assumptions total expenditure is projected to increase to $£ 47.0$ bn by 2032 , an increase of 168 per cent; and under very high LE assumptions total expenditure is projected to increase to $£ 55.7 \mathrm{bn}$, an increase of 218 per cent. 


\section{Table 5 Long-term care expenditure, by expenditure source under variant life expectancy assumptions from 2007 to 2032, England}

\begin{tabular}{|c|c|c|c|c|c|c|c|c|}
\hline & & 2007 & 2012 & 2017 & 2022 & 2027 & 2032 & $\begin{array}{r}\text { £billions } \\
\text { Percentage } \\
\text { increase } \\
\mathbf{2 0 0 7 - 2 0 3 2}\end{array}$ \\
\hline & Public & 11.2 & 12.9 & 15.3 & 18.7 & 22.9 & 28.4 & 153.7 \\
\hline & Private & 6.3 & 7.5 & 9.3 & 11.6 & 14.9 & 18.6 & 193.7 \\
\hline \multirow[t]{3}{*}{ LLE } & Total & 17.5 & 20.5 & 24.7 & 30.2 & 37.7 & 47.0 & 168.2 \\
\hline & Public & 11.2 & 13.0 & 15.5 & 19.1 & 23.8 & 30.1 & 168.9 \\
\hline & Private & 6.3 & 7.6 & 9.5 & 11.9 & 15.5 & 19.8 & 212.2 \\
\hline \multirow[t]{3}{*}{ PLE } & Total & 17.5 & 20.6 & 25.1 & 31.0 & 39.3 & 49.9 & 184.6 \\
\hline & Public & 11.2 & 13.1 & 15.8 & 19.6 & 24.7 & 31.8 & 184.2 \\
\hline & Private & 6.3 & 7.7 & 9.7 & 12.2 & 16.1 & 21.0 & 230.9 \\
\hline \multirow[t]{3}{*}{ HLE } & Total & 17.5 & 20.8 & 25.4 & 31.8 & 40.8 & 52.8 & 201.1 \\
\hline & Public & 11.2 & 13.2 & 16.0 & 20.1 & 25.7 & 33.5 & 199.7 \\
\hline & Private & 6.3 & 7.7 & 9.8 & 12.5 & 16.8 & 22.1 & 249.6 \\
\hline VHLE & Total & 17.5 & 21.0 & 25.9 & 32.7 & 42.4 & 55.7 & 217.7 \\
\hline
\end{tabular}

1 LLE low life expectancy variant, PLE principal life expectancy projection, HLE high life expectancy variant, VHLE very high life expectancy variant

Source: PSSRU and CARESIM model estimates

As table 6 shows, in 2007 public expenditure on LTC was roughly 0.9 per cent of GDP. Under each LE variant examined here public expenditure as a percentage of GDP is projected to increase in future years. Under the principal LE projection public expenditure could reach around 1.6 per cent of GDP by 2032, but under the low and very high LE variants public expenditure could reach between 1.5 per cent and 1.7 per cent of GDP by 2032, respectively. 


\section{Table 6 Long-term care public expenditure as a percentage of GDP, under different life expectancy assumptions from 2007 to 2032, England}

\begin{tabular}{|lrrrrrrr|}
\hline & & & & & & \multicolumn{2}{r|}{ Percentage } \\
England & & $\mathbf{2 0 0 7}$ & $\mathbf{2 0 1 2}$ & $\mathbf{2 0 1 7}$ & $\mathbf{2 0 2 2}$ & $\mathbf{2 0 2 7}$ & $\mathbf{2 0 3 2}$ \\
regime & LLE & 0.9 & 1.0 & 1.1 & 1.2 & 1.4 & 1.5 \\
& PLE & 0.9 & 1.0 & 1.1 & 1.2 & 1.4 & 1.6 \\
& HLE & 0.9 & 1.0 & 1.1 & 1.3 & 1.5 & 1.7 \\
& VHLE & 0.9 & 1.0 & 1.1 & 1.3 & 1.5 & 1.8 \\
Partnership & & & & & & & \\
& LLE & 1.0 & 1.0 & 1.1 & 1.3 & 1.4 & 1.6 \\
& PLE & 1.0 & 1.0 & 1.1 & 1.3 & 1.5 & 1.7 \\
& HLE & 1.0 & 1.1 & 1.2 & 1.3 & 1.5 & 1.8 \\
& VHLE & 1.0 & 1.1 & 1.2 & 1.4 & 1.6 & 1.9 \\
\hline
\end{tabular}

1 LLE low life expectancy variant, PLE principal life expectancy projection, HLE high life expectancy variant, VHLE very high life expectancy variant

Source: PSSRU and CARESIM model estimates

\section{Effect on expenditure of a partnership scheme}

The effect of implementing the partnership scheme on public expenditure as a percentage of GDP, including expenditure on disability benefits used to fund care, is shown in Table 6 under variant LE assumptions. Depending on the LE variant, by 2032 the current funding system could cost the state anywhere between 1.5 per cent and 1.8 per cent of GDP. By contrast the partnership scheme could cost anywhere between 1.6 per cent and 1.9 per cent of GDP. In effect, the partnership scheme would add an extra 0.1 per cent of GDP to the public cost of LTC, which is roughly equivalent to $£ 1$.3bn to $£ 1.5 \mathrm{bn}$ over the current funding system by 2032 depending on whether LE improves in line with the principal or very high LE variant respectively.

\section{Future expenditure on long-term care and pensions}

Table 7 brings together estimates for state expenditure on both pensions and LTC as a percentage of GDP. State expenditure on pensions is roughly five times expenditure on LTC in 2007.

However, by 2032, pension expenditure is about 3.5 to four times greater than LTC expenditure.

Under the principal LE assumption and assuming that pension and LTC funding policy does not change, the combined expenditure of both programmes rises from 5.6 per cent of GDP in 2007 to 7.8 per cent in 2032. However, should mortality rates decline faster, then public expenditure could reach 8.1 per cent of GDP under the high LE assumption and 8.6 per cent under the very high LE assumption. Were the partnership model for LTC funding to be implemented, state expenditure on pensions and LTC in 2032 would be higher by an amount equal to roughly 0.1 per cent of GDP under each LE assumption. 


\section{Table 7 Public expenditure on long-term care and pensions as a percentage of GDP, under different life expectancy assumptions, England 2007 to 2032}

\begin{tabular}{|c|c|c|c|c|c|c|c|c|}
\hline & & & & & & & \multicolumn{2}{|c|}{ Percentage } \\
\hline \multirow{3}{*}{$\begin{array}{l}\text { Current funding } \\
\text { regimes }\end{array}$} & \multirow[b]{2}{*}{ PLE } & & 2007 & 2012 & 2017 & 2022 & 2027 & 2032 \\
\hline & & LTC & 0.9 & 1.0 & 1.1 & 1.2 & 1.4 & 1.6 \\
\hline & & Pensions & 4.7 & 4.8 & 5.1 & 5.3 & 5.5 & 6.2 \\
\hline & & Total & 5.6 & 5.8 & 6.2 & 6.5 & 6.9 & 7.8 \\
\hline & HLE & LTC & 0.9 & 1.0 & 1.1 & 1.3 & 1.5 & 1.7 \\
\hline & & Pensions & 4.8 & 4.9 & 5.2 & 5.4 & 5.7 & 6.4 \\
\hline & & Total & 5.7 & 5.9 & 6.3 & 6.7 & 7.2 & 8.1 \\
\hline & VHLE & LTC & 0.9 & 1.0 & 1.1 & 1.3 & 1.5 & 1.8 \\
\hline & & Pensions & 5.0 & 5.1 & 5.4 & 5.7 & 6.0 & 6.8 \\
\hline & & Total & 5.9 & 6.1 & 6.5 & 7.0 & 7.5 & 8.6 \\
\hline Current pension & PLE & LTC & 1.0 & 1.0 & 1.1 & 1.3 & 1.5 & 1.7 \\
\hline regime and & & Pensions & 4.7 & 4.8 & 5.1 & 5.3 & 5.5 & 6.2 \\
\hline partnership model & & Total & 5.7 & 5.8 & 6.2 & 6.6 & 7.0 & 7.9 \\
\hline for LTC & HLE & LTC & 1.0 & 1.1 & 1.2 & 1.3 & 1.5 & 1.8 \\
\hline & & Pensions & 4.8 & 4.9 & 5.2 & 5.4 & 5.7 & 6.4 \\
\hline & & Total & 5.8 & 6.0 & 6.4 & 6.7 & 7.2 & 8.2 \\
\hline & VHLE & LTC & 1.0 & 1.1 & 1.2 & 1.4 & 1.6 & 1.9 \\
\hline & & Pensions & 5.0 & 5.1 & 5.4 & 5.7 & 6.0 & 6.8 \\
\hline & & Total & 6.0 & 6.2 & 6.6 & 7.1 & 7.6 & 8.7 \\
\hline
\end{tabular}

1 PLE principal life expectancy projection, HLE high life expectancy variant, VHLE very high life expectancy variant Source: PSSRU, CARESIM and PPI model estimates

\section{Discussion}

Improvements in LE have two effects: they increase the size of the older population and they increase the numbers of people living into ever older ages, such that the numbers of oldest old are projected to grow more quickly in the coming decades than the older population as a whole. Over the period examined here, from 2007 to 2032, the effect of improvements in LE on state expenditure on pensions and LTC is intuitive; expenditure on pensions and associated benefits is projected to rise in future years because of the increasing numbers of pensioners - more recent projections allowing for the further policy changes described above confirm this, and show even faster growth (PPI 2011) ; and expenditure on LTC is projected to rise, although at a faster rate than pensions expenditure. The faster rate of growth in LTC expenditure is partly a consequence of the faster rate of growth of the oldest old group compared to the older population as a whole, as it is at the oldest ages where need for care is the greatest.

If LE improves more than is assumed under the principal population projection, the effect on state pension and LTC expenditure could be quite substantial. If LE rises in line with the high LE variant then by 2032 Government would need to find an additional 0.2 per cent of GDP to finance the pensions system and an additional 0.1 per cent GDP to finance the LTC system. Should LE follow 
the very high LE variant then by 2032 Government would need to find an additional 0.6 per cent of GDP, equivalent to roughly $£ 11 \mathrm{bn}$, to finance the pensions system, and an additional 0.2 per cent of GDP, or $£ 3.4 \mathrm{bn}$, to finance the LTC system. The effect of improvements in LE on pensions and LTC expenditure taken together provides a starker picture since the programmes considered together represent a substantial amount of state expenditure, projected to rise from 5.6 per cent GDP in 2007 to 7.8 per cent of GDP by 2032 under the principal LE assumption and 8.6 per cent under the very high LE. Given the uncertainty surrounding LE projections it is important that the Government allows for the possibility of faster than expected improvements in LE when considering the potential costs of policy reforms and considers the effects that improvements in LE can have on multiple systems when considering the affordability and sustainability of state funded programmes.

Income from private pensions is also projected to increase over the period examined here, although the rise is significantly more modest than that found for state pensions (and could be further tempered if pension providers reduce annuity rates in response to increases in LE). This pattern can be understood as a consequence of policy changes. Thus income from private pensions increases initially, but starts to fall back as DB is replaced by DC. However, spending on state pensions increases over the period as the numbers over SPA increase and pensions become more generous.

Private expenditure on LTC is projected to grow faster than public expenditure on LTC over the period examined here accounting for 40 per cent of total expenditure by 2032 compared to 36 per cent in 2007. This is due to an increase in the proportion of care recipients who fund 100 per cent of their care, which is largely explained by further increases in owner-occupation at the oldest ages. The reliance on private funding highlights the challenges there are around reforming the LTC system, since most private expenditure is out of pocket and a small proportion of people can face costs that are 'catastrophic': it has been estimated that seven per cent of people aged 65 will face lifetime care costs of at least $£ 100,000$, and 5 per cent of at least $£ 200,000$ (Fernández and Forder 2011). Policymakers will need to respond to these challenges in taking forward proposals for LTC reform.

The partnership scheme examined here as an alternative to the current system was designed to address some of the perceived failures of the current system, notably that it produces significant unmet need (Wanless 2006; Commission for Social Care Inspection 2008) and creates disincentives to save and plan for LTC needs (Mayhew et al., 2010). The particular version of the partnership scheme modelled here would require the state to find an additional 0.1 per cent GDP by 2032 to finance it, irrespective of which assumption about improvements in LE is made.

A key question that we have not addressed in this paper is how and from whom funds to meet higher state spending on LTC or pensions, whether as a result of funding reforms or higher LE, would be raised. Thus we are not able to comment on the effects of alternative methods of raising the revenue that we project would be needed for a partnership scheme or other reform to the LTC funding system or to keep pace with higher LE.

A further limitation is that we have accounted only partially for the links between spending on pensions and LTC at the micro level, which are important for understanding the effects of potential reforms. Since LTC is a means-tested system any increases in pensioners' incomes and wealth 
shifts the balance of funding away from the state onto individuals. Making state pensions less generous would shift the balance of funding for LTC from the individual towards the state. Understanding and being able to quantify the effect of changes to both the state and private pensions, such as raising the SPA and the move from DB to DC plans, on the LTC system will help to identify appropriate funding models for the future.

There are also some limitations associated with the modelling that are likely to affect the figures presented here. We have not modelled a link between improvements in LE and socio-economic status. However, it is possible that the gains in LE will be concentrated amongst wealthier older people (Nazroo et al., 2008), which is likely to accentuate the trend towards individuals taking a greater burden of responsibility for payment of LTC. It could also increase private pension income more than state pensions and means-tested benefits since it tends to be wealthier individuals who have private pensions and by definition are less likely to be entitled to means-tested benefits in retirement.

In addition, in both the LTC and pension modelling we have not taken into account changes in behaviour resulting from reforms. We identified that a more generous system may lead to increased demand for care. However, it is also the case that residential care and nursing home providers may react to changes in the balance of purchases for places by state and self-funded residents. Self funders currently pay higher fees for their places than state-funded residents so any change in the balance of self-to state-funded residents will affect provider income and the sustainability of the homes (Hancock and Hviid 2010). Equally in the pensions context, the savings behaviour of individuals may be affected by auto-enrolment into pensions and other planned changes in the pension system. This could be a direct effect, changing the amounts that individuals save, or an indirect effect through the behaviour of employers and the levels of contributions that they offer into workplace pension schemes. Given the considerable changes in both the state and private pension systems in recent years, future behaviour may be very different from that seen in the past.

Policy reform in the area of pensions and LTC is a rapidly moving field and we have not included in our modelling some planned-for changes to the pensions system, notably the Coalition legislation to bring forward the increase in SPA, the provision of the 'triple guarantee' mentioned earlier and the move to the use of the Consumer Price Index (CPI) for uprating of state pensions. Since the original announcement on the first of these, the government has decided to put back the increase by six months. The long term link of BSP to the triple guarantee may also come under pressure given the fact that the $\mathrm{CPI}$ is rising considerably faster than earnings. We have also not taken into account forthcoming reforms to public sector pension schemes resulting from the recent Hutton Review, restrictions on the availability of tax relief on pension contributions (from April 2011), and the ending of the requirement to purchase an annuity with the proceeds of a DC pension by age 75 (from April 2011). Nor have we taken into consideration any of the state pension reforms proposed by the Government in its recent Green Paper (Department for Work and Pensions 2011).

The assumptions about GDP that we are using are likely to be optimistic since they pre-date the financial crisis. More recent figures released by the Treasury for short-term growth are lower than those assumed here. However, the long-term projections for annual real growth used in the model are lower than those currently assumed by the Treasury, meaning that the long-term projections of the proportion of GDP absorbed by LTC and pensions would not be substantially changed and if 
anything are slightly too high. Additionally our assumptions about wage growth in the LTC sector may be high for the short-term since they assume a two per cent real rise in staff costs. Given pressures on local government budgets and current trends in the wider economy such a rise seems unlikely unless restrictions on immigration push up costs. Previous work has demonstrated the sensitivity of projections to changes in unit costs (Malley et al., 2006; Wittenberg et al., 2006), so if wage growth is slower it will offset some of the cost increases due to improvements in LE.

\section{Conclusion}

The purpose of this analysis has been to assist decision-makers developing proposals for the reform of the systems for state pensions and for LTC of older people. This is in the context of continuing debates about both these systems. The debates have been prompted partly by concerns about equity and fairness but substantially by concerns about the future fiscal sustainability of public expenditures on the Welfare State in the face of ageing populations.

The analysis shows that projected future expenditure on pensions and related benefits and on LTC for older people is sensitive to variant assumptions about future mortality rates and life expectancy. Moreover the projected future costs of specific reforms are also sensitive to variant assumptions about future mortality rates and life expectancy. This means that policy-makers developing reform proposals need to recognise that, since future life expectancy is inevitably uncertain, there is considerable uncertainty about the likely impact of demographic pressures on future public expenditure on pensions and LTC. They need to prepare in particular for the possibility that the pressures could prove greater than would be expected on the basis of the ONS principal population projections.

The projections presented in this paper, by considering the pensions and LTC systems together, take a step toward drawing together the debates on reform of the two systems. It seems appropriate that reforms of these two systems should be considered together since both affect the resources and well-being of the older population and both raise issues for financial decisionmaking in middle age, especially decisions relating to saving for old age. Joint policy debate on these two issues would be greatly assisted by joint analyses. Further research looking in more detail at the interactions between pension and LTC reforms in the context of uncertainty about the size of future demographic pressures on public expenditure on these two services would be very valuable.

\section{Acknowledgements}

This paper arises from work undertaken as part of the Modelling Ageing Populations to 2030 (MAP2030) project funded under a grant from the New Dynamics of Ageing Programme, a crossresearch council programme (RES-339-25-0002). Material from the Family Resources Survey and the General Household Survey is crown copyright and has been made available via the UK Data Archive. All responsibility for analysis and interpretation and views expressed rests with the authors. 


\section{References}

Abel G, Bijak J and Raymer J (2010). "A comparison of official population projections with bayesian time series forecasts for England and Wales." Population Trends 141: 95-114.

Christensen K, Doblhammer G, Rau R and Vaupel J W (2009). "Ageing populations: The challenges ahead." The Lancet 374: 1196-1208.

Comas-Herrera A, Butterfield R, Fernández J L, Wittenberg R and Wiener J M (2011). Barriers and opportunities for private long-term care insurance in England: What can we learn from other countries? Elgar Edward handbook of health policy. C.-F. J. a. M. A, Elgar Edward.

Comas-Herrera A, Wittenberg R and Pickard L (2004). Long-term care for older people in the United Kingdom: Structure and challenges. . Long-term care: Matching resources and needs. Knapp M, Challis D, Fernández J-L and Netten A. Aldershot, Ashgate: 17-34.

Commission on Funding Care and Support (2011) Fairer Care Funding: the report of the Commission on Funding Care and Support available at: http://www.dilnotcommission.dh.gov.uk/files/2011/07/Fairer-Care-Funding-Report.pdf

Commission for Social Care Inspection (2008). Cutting the cake fairly: CSCI review of eligibility criteria for social care. London, Commission for Social Care Inspection,

Department for Work and Pensions (2011). A state pension for the 21st century. CM 8053. London, TSO

Department of Health (2000). The NHS plan: The government's response to the Royal Commission on long-term care. CM 4818-ii. London, TSO

Department of Health (2003). Fairer charging policies for home care and other non-residential social services. Guidance for councils with social services responsibilities. London, Department of Health

Department of Health (2010). Prioritising need in the context of putting people first: A whole system approach to eligibility for social care - guidance on eligibility criteria for adult social care, England 2010. London, Department of Health

Donald I, Foy C and Jagger C (2010). "Trends in disability prevalence over 10 years in older people living in Gloucestershire." Age and Ageing 39(3): 337-342.

Dunnell K. (2008). "Ageing and mortality in the UK - national statistician's annual article on the population." Population Trends 134: 6-23.

European Commission and Economic Policy Committee (2009) The 2009 Ageing Report:

Economic and budgetary projections for the EU - 27 member states. European Economy 2|2009.

Brussels, European Commission 
Fernández J- L and Forder J (2011). Impact of changes in length of stay on the demand for residential care services in England, report commissioned by bupa care services. PSSRU discussion paper 2771. Canterbury, PSSRU

Government Office for Science (2007). Tackling obesities: Future choices. Foresight project report Hancock R, Comas-Herrera A, Wittenberg R and Pickard L (2003). "Who will pay for long-term care in the UK? Projections linking macro- and micro-simulation models." Fiscal Studies 24(4): 387-426.

Hancock R. and Hviid M (2010). Buyer power and price discrimination: The case of the UK care homes market. Ccp working paper 10-17. Norwich, University of East Anglia, Centre for Competition Policy

Hancock R, Pickard L, Wittenberg R, Comas-Herrera A, Juarez-Garcia A, King D and Malley J (2007). Paying for long-term care for older people in the UK: Modelling the costs and distributional effects of a range of options. Report to the Nuffield Foundation. PSSRU discussion paper 2336/2. London, Personal Social Services Research Unit

Her Majesty's Government (2009). Shaping the future of care together, CM 7673. London, The Stationery Office

Her Majesty's Government (2010). Building the national care service. CM 7854. London, The Stationery Office

HM Treasury (2008). Long-term public finance report: An analysis of fiscal sustainability. Annex a: Illustrative long-term projections. London, TSO

HM Treasury (2010). Spending review 2010. CM 7942. London, TSO

Jagger C, Matthews R, Lindesay J, Robinson T, Croft P and Brayne C (2009). "The effect of dementia trends and treatments on longevity and disability: A simulation model based on the MRC cognitive function and ageing study (MRC CFAS)." Age and Ageing 38(3): 319-325.

Jagger C., Matthews R J, Matthews F E, Spiers N A, Nickson J, Paykel E S, Huppert F A, Brayne C and Medical Research Council Cognitive Function and Ageing Study (MRC-CFAS) (2007). "Cohort differences in disease and disability in the young-old: Findings from the MRC cognitive function and ageing study (MRC-CFAS)." BMC Public Health 7(156).

Keilman N. (2007). "UK national population projections in perspective: How successful compared to those in other European countries?" Population Trends 129: 20-30.

Lloyd J. (2008). Funding long-term care - the building blocks of reform. London, International Longevity Centre - UK

Malley J, Comas-Herrera A, Hancock R, Juarez-Garcia A, King D and Pickard L (2006).

Expenditure on social care for older people to 2026. London, King's Fund 
Marmot M, Allen J, Goldblatt P, Boyce T, McNeish D, Grady M and Geddes I (2010). Fair society, healthy lives. Strategic review of health inequalities in England post-2010. London

Mayhew L., Karlsson M and Rickayzen B (2010). "The role of private finance in paying for long term care." The Economic Journal 120(548): F478-F504.

Murphy M. (1995). "The prospect of mortality: England and Wales and the United States of America 1962-1989." British Actuarial Journal 1(2): 331-350.

Murphy M. (2009). "The 'golden generations' in historical context." British Actuarial Journal 15, Supplement: 151-184.

Murphy M and Di Cesare M (2012, forthcoming) "The impact of smoking-related deaths on changes in British cohort mortality." Population Studies.

Nazroo J, Zaninotto P and Gjonça E (2008). Chapter 8. Mortality and healthy life expectancy living in the 21st century: Older people in England._The 2006 English longitudinal study of ageing (wave 3). Banks J, Breeze E, Lessof C and Nazroo J. London, Institute for Fiscal Studies.

Office for Budget Responsibility (2011) Fiscal Sustainability Report: July 2011. The Stationery Office, London.

Office for National Statistics "Trends in ONS longitudinal study estimates of life expectancy, by social class 1972-2005." Accessible at: http://www.ons.gov.uk/ons/rel/health-ineq/healthinequalities/trends-in-life-expectancy-by-social-class-1972-2005/trends-in-ons-longitudinal-studyestimates-of-life-expectancy-1972-2005.pdf

Office for National Statistics (2009) "2008-based national population projections." Accessible at: http://www.ons.gov.uk/ons/rel/npp/national-population-projections/2008-basedprojections/index.html

Office for National Statistics (2010) "National population projections 2008-based. Series pp2 no 27." Accessible at: http://www.ons.gov.uk/ons/rel/npp/national-population-projections/2008-basedreference-volume--series-pp2/2008-based-reference-volume-no--27.pdf

Office of Population Censuses and Surveys (1995). National population projections 1992-based. Series pp 2 no. 18. London, HMSO

Olshansky S J, Passaro D J, Hershow R C, Layden J, Carnes B A, Brody J, Hayflick L, Butler R N, Allison D B and Ludwig D S (2005). "A potential decline in life expectancy in the United States in the 21st century." New England Journal of Medicine 352: 1138-45.

Organisation for Economic Cooperation and Development (2005). Long-term care for older people, OECD Publishing.

Pensions Commission (2005). A new pension settelment for the twenty-first century. The second report of the pensions commission. Appendix $\mathrm{E}$ uncertainties in life expectancy projections. London, TSO:179-192 
Pensions Commission (2006). Implementing an integrated package of pension reforms. Final report of the pensions commission. London, The Stationery Office

Pensions Policy Institute (2007). Will Personal Accounts increase pension saving? London, Pensions Policy Institute

Pensions Policy Institute (2011). An assessment of the Government's options for state pension reform London, Pensions Policy Institute

Royal Commission on Long-term Care (1999). With respect to old age: Long term care - rights and responsibilities, cm 4192-I. London, TSO

Secretary of State for Health (2010). Terms of reference for the commission on the funding of care and support. Written ministerial statement

Shaw C. (2007). "Fifty years of United Kingdom national population projections: How accurate have they been?" Population Trends 128: 8-23.

Steventon A. (2005). What will pensions cost in the future? London, Pensions Policy Institute Wanless D. (2006). Securing good care for older people. Taking a long-term view. London, King's Fund

Wittenberg R, Comas-Herrera A, King D, Malley J, Pickard L and Darton R (2006). Future demand for long-term care, 2002 to 2041: Projections of demand for long-term care for older people in England, PSSRU discussion paper 2330. Canterbury, Personal Social Services Research Unit 